\title{
EVALUATION OF THE MULTIPROFESSIONAL WORK OF THE FAMILY HEALTH SUPPORT CENTER (NASF) ${ }^{1}$
}

\author{
Mary Lopes Reis ${ }^{2}$, Marcelo Medeiros ${ }^{3}$, Leonora Rezende Pacheco ${ }^{4}$, Camila Cardoso Caixeta ${ }^{5}$
}

\footnotetext{
${ }^{1}$ This study is originated from the dissertation - Social dimension of nurse's work in family health strategy, being written for the Graduate Program of the School of Nursing (PPG-ENF) of the Universidade Federal de Goiás (UFG), funded by CAPES.

${ }^{2}$ Doctoral Student at the PPG-ENF/UFG. Goiânia, Goiás, Brazil. E-mail: marylore6@hotmail.com

${ }^{3}$ Ph.D. in Nursing. Professor at the School of Nursing of UFG. Goiânia, Goiás, Brazil. E-mail: marcelofen@gmail.com

${ }^{4}$ M.Sc. in Nursing. Professor in the Department of Nursing at the Universidade Federal de Tocantins. Palmas, Tocantins, Brazil. E-mail: lerezende@hotmail.com

${ }^{5}$ Ph.D. in Nursing. Professor at the School of Nursing of UFG. Goiânia, Goiás, Brazil. E-mail: camilaccaixeta@uol.com.br
}

\begin{abstract}
The aim of this study was to understand the meanings attributed by the actors (social assistant, physical educator, pharmacist, nutritionist, and psychologist) to the work developed at a Family Health Support Center. A descriptive study with a qualitative focus was carried out by a focus group with 14 health professionals belonging to the center whose data were analyzed by means of a thematic content analysis. Three categories emerged: "interdisciplinarity", "lack of knowledge of the territory," and the "Support Center's isolation". Through this research it was possible to realize that interdisciplinarity has been sought after by the Support Center's professionals. However, this performance does not include the Family Health teams linked to the center, except in specific situations of mental health when Matrix Support is used for discussing and guiding the cases presented by the Family Health Strategy teams.
\end{abstract}

DESCRITORES: Family health. Primary health care. Interdisciplinarity.

\section{AVALIAÇÃO DO TRABALHO MULTIPROFISSIONAL DO NÚCLEO DE APOIO À SAÚDE DA FAMÍLIA (NASF)}

\begin{abstract}
RESUMO: O objetivo do estudo foi compreender os significados atribuídos pelos atores (assistente social, educador físico, farmacêutico, nutricionista e psicólogo) ao trabalho desenvolvido em uma unidade do Núcleo de Apoio à Saúde da Família. Estudo descritivo de cunho qualitativo, realizado por meio de grupo focal, com 14 profissionais de saúde pertencentes ao Núcleo, cujos dados foram analisados por análise de conteúdo modalidade temática. Emergiram três categorias "interdisciplinaridade", "território desconhecido" e "isolamento do Núcleo interprofissional". Os dados apontam que a interdisciplinaridade tem sido perseguida pelos profissionais atuantes na equipe do Núcleo. No entanto, essa atuação diferenciada não se estende às equipes de Saúde da Família vinculadas, salvo em situações específicas de saúde mental, quando há utilização do Apoio Matricial para discussão e condução dos casos apresentados pelas equipes da Estratégia de Saúde da Família.
\end{abstract}

DESCRITORES: Saúde da família. Atenção primária. Interdisciplinaridade.

\section{EVALUACIÓN DEL TRABAJO MULTIPROFESIONAL EN EL NÚCLEO DE APOYO A LA SALUD DE LA FAMÍLIA (NASF)}

RESUMEN: El objetivo del estudio fue comprender los significados de los actores (trabajadores sociales, educadores físicos, farmacéutico, nutricionista y psicólogo) en su labor en la unidad del Núcleo de Apoyo a la Salud de la Familia. Estudio descriptivo con enfoque cualitativo, llevado a cabo a través de grupos focales con 14 profesionales de la salud en el Núcleo, cuyos datos fueron analizados empleando el análisis de contenido temático. Los análisis han resultado en tres categorías: "interdisciplinariedad", "territorio desconocido" y "aislamiento del núcleo interprofesional". Los datos indican que la interdisciplinariedad ha sido perseguida por los profesionales que trabajan en el Núcleo. Sin embargo, esta actuación diferenciada no abarca el trabajo de los otros equipos de salud, excepto em situaciones específicas de salud mental, cuando se utiliza la herramienta de 'Apoyo Matricial' para la discusión y el manejo de los casos presentados por los equipos de la Estrategia de Salud de la Familia.

DESCRIPTORES: Salud de la familia. Atención primaria de salud. Interdisciplinariedad. 


\section{INTRODUCTION}

The strengthening of primary health care as the gateway into the Unified Health System (SUS, as per its Portuguese acronym), expanding the population's access to the promotion and prevention actions, as well as improving the quality of the care provided by the health professionals, presupposes that some strategies should be used to ensure basic training, improvement, and to increase responsiveness by the professionals who work directly on the care services for families, such as the family health teams. ${ }^{1}$ The Family Health Support Center (NASF, as per its Portuguese acronym) is one such strategy adopted by the Ministry of Health $(\mathrm{MoH})$ to achieve the objectives in primary care. It is a multidisciplinary team created by the MoH by Ordinance GM no. $154 / 2008,{ }^{2}$ which is composed of professionals according to the local need (social assistant, physical educator, pharmacist, physiotherapist, nutritionist, psychologist, psychiatrist, occupational therapist, and others). Its main objective is to assist in changing attitudes and actions of the family health professionals through broadening the scope of primary health care actions. ${ }^{3}$

A holistic approach is NASF's main guideline applied in three ways: the individual, the health practices, and the organization of the health system. In addition, other principles guide the actions developed by NASF such as territory, health education for the people, interdisciplinarity, social participation, intersectoral, permanent health education, humanization, and health promotion. ${ }^{3}$

In addition to NASF's efforts to ensure and expand the responsiveness of the work done by the FHS teams, the MoH also created the National Program for Improving Access and the Quality of Primary Health Care (PMAQ, Portuguese acronym) ${ }^{4}$ which is aimed at developing primary care in the sense of access and quality of the SUS. The latter is a monitoring program aimed at identifying the strengths and critical points of the FHS and to propose measures to strengthen their responsiveness, which consists of four phases that make up a cycle, namely: contracting or adherence, development, external evaluation, and re-contracting. In PMAQ's development phase there is a self-assessment stage by the managers and teams in order to guide the results to be achieved by the FHS teams.

The evaluation can be viewed as a process by which understanding is gained of the reality in order to support the decision-making process. ${ }^{5-6}$ Specifically in the area of health, in the context of the SUS, the evaluation process must take into account the real needs of each municipality and be committed to building an institutional culture of continuous evaluation, the development of human resources, and the pursuit of quality in the care given. ${ }^{7}$

In this sense, since the Ministry of Health did not include the NASF teams in the Evaluation Program, the Telehealth Center of Santa Catarina, based on the PMAQ, developed a self-assessment tool for NASF (AMAQ-NASF SC) because of the need to monitor the implementation of this strategy in different realities of primary health care. ${ }^{8}$ The aim is to promote discussion and reflection on critical points to be improved in order to achieve the NASF objectives in "expanding the scope of views and actions in primary health care, helping toward longitudinality and comprehensiveness with the inclusion of different professionals at this level of care" .8:20

Assuming that new strategies implemented need monitoring and adjustments to the critical points highlighted and, in order to shed light on aspects of the work done at the NASF, contributing to the discussion on aspects of interdisciplinarity and responsiveness in primary health care, the aim of this study was to understand the meanings attributed by the actors (social assistant, physical educator, pharmacist, nutritionist, and psychologist) to the work developed at an NASF.

\section{METHOD}

Descriptive qualitative research that provides an in-depth analysis of the meanings attributed by the subjects within the context studied. ${ }^{9}$

Considering the diversity of the composition of the NASF teams due to their own design presented in the guidelines for NASF, ${ }^{3}$ at the site of our study there are three NASF teams. Each team has in its composition a total of five undergraduate professionals. At the first team there is a social assistant, a physical educator, a pharmacist, a nutritionist, and a psychologist. In team two there is no physical educator, but two nutritionists. In team three there is no social assistant, but two psychologists.

The state was developed in a Brazilian state capital city that has about $700 \mathrm{~km} 2$ of land area and a total population greater than 1.2 million inhabitants in 2010 according to IBGE estimates. The capital city serves as a benchmark in health care for the other municipalities in the state and other regions of Brazil.

This capital city has fifty-six Family Primary Health Care Units (UABSF, as per its Portuguese acronym) distributed into six health districts. The 
study was conducted in the largest health district of the capital city, which has a population of 178,000 inhabitants. This health district has in its structure one maternity ward, three comprehensive health care centers, one psychosocial care center, and eighteen UABSFs in which are distributed fifty-one family health (FHS) teams. It is the only district of the capital city that has NASF teams.

Fourteen professionals who are part of the three NASF teams of the health district and signed a free and informed consent form participated in the study. It should be noted that during the evaluation process one of NASF workers submitted a request to be transferred to another health care unit.

Data collection was performed based on a self-evaluation process of NASF and carried out by a professional that is not part of the Municipal Health Department, by conducting a focus group with the workers of NASF that was recorded on video. In the self-evaluation process, initially it was proposed that the NASF teams would answer the AMAQ-NASF SC instrument ${ }^{8}$ as a starting point.
Thus, one researcher coordinated the necessary meetings with each of the three NASF teams, who together answered the instrument.

After the consolidation of the results of each team, a focus group was carried out with all the NASF workers for discussion about the points that were considered important. In this focus group the participants were divided into four groups in order to discuss for twenty minutes each of the sub-dimensions evaluated within the dimension "Consolidation of the Health Care Model" of the AMAQ-NASF SC Instrument. Each group prepared a report of the discussions and presented it to the large group, which took twenty minutes for discussion.

Table 1 shows the distribution of the subdimensions contained in the AMAQ NASF SC instrument related to the work of the NASF teams discussed by the four groups during the focus group. It should be noted that there was a concern to keep at least one representative from each NASF team in each group and, where possible, prioritize the diversity of professional categories.

Table 1 - Distribution of the groups according to the themes discussed - focus group NASF 2013

\begin{tabular}{|l|l|}
\hline \multicolumn{1}{|c|}{ Groups } & \multicolumn{1}{|c|}{ Theme or sub-dimension* } \\
\hline Group 1 - social assistant, pharmacist, and two psychologists & Organization and work process of the NASF team \\
\hline Group 2 - physical educator, pharmacist, and two nutritionists & Shared actions in the territory \\
\hline Group 3 - physical educator, pharmacist, and psychologist & Shared actions at the health unit \\
\hline Group 4 - social assistant, nutritionist, and psychologist & Specific actions of the NASF professionals \\
\hline
\end{tabular}

*According to the AMAQ-NASF SC instrument ${ }^{8}$

The discussions of the focus group were recorded on a digital media for subsequent transcription of what the participants said and analysis according to the proposal of thematic content analysis. ${ }^{10}$ The codification process took place in three stages with the first being an exhaustive reading of all transcripts and identifying the main ideas contained in the statements. The second stage was when these ideas were grouped by similarity into units of meaning, which were regrouped resulting in the category themes of "interdisciplinarity", "lack of knowledge of the territory," and "isolation of the NASF". The third stage was to draft a treatment of the results through a dialog between the issues, objectives, and literature. ${ }^{9-10}$

To present the results, the transcribed words were identified by the letter " $G$ " followed by the number corresponding to the group when referring to the content presented by the group after the discussion of the sub-dimensions. The statements that refer to further discussion in the large group will be identified by the letter " $\mathrm{P}$ " followed by the participant number according to the distribution of participants in the circle during the focus group.

The study was reviewed and approved by the Research Ethics Committee of the Universidade Federal de Goiás (protocol 117/13) and the Municipal Health Department of the capital city under study.

\section{RESULTS AND DISCUSSION}

\section{Characterization of the subjects}

We found a relatively young and highly qualified team where most have been building their career in primary care with experience of a little more than two years in the implementation of the NASF in the capital city studied.

There is a predominance of female workers (71.5\%). In terms of age, $64 \%$ are between the ages of 31 and 40 years old followed by $28.5 \%$ over 50 years 
old. In all, fourteen professionals make up the three NASF teams: three pharmacists, three nutritionists, four psychologists, two social assistants, and two physical educators. The time since their graduation in their area of expertise is mostly between six to ten years $(42.8 \%)$ and the rest are divided between ten to fifteen years $(28.5 \%)$, and over fifteen years $(28.5 \%)$. As for time working in the FHS, for one it has been less than one year, for $50 \%$ it has been between one and two years, and for $21.4 \%$ it has been between two to five years or five to ten years. Just over 50\% of the professionals started their activities in the FHS as already part of the NASF team. As for further training, $50 \%$ of the professionals have a specialization in family health; only two professionals do not have a graduate degree, a master's degree, or a master's in progress; one professional has a doctorate degree, and five professionals have more than one specialization degree. Two specializations are in their specific area (pharmaceutical sciences and physical education) whereas the others are in multidisciplinary areas: health education, mental health, social policies, and public health. Therefore, it is our understanding that this vocational qualification brings a significant differential in the care provided.

The categories "interdisciplinarity", "lack of knowledge of the territory," and "isolation of the NASF" will be presented and discussed below.

\section{Interdisciplinarity}

The interdisciplinary approach is a principle that permeates all the work of NASF, which is understood as an action, an experience among professionals from different disciplines that reflects the permeability of concepts, ways of relating, and characteristic skills of a particular body of knowledge that make up each professional practice. ${ }^{3}$ It requires integration and a close relationship between knowledge and practice, between understanding and action. ${ }^{11-12}$

When answering the AMAQ-NASF SC instrument, ${ }^{8}$ the subjects in this study rated their work process as "satisfactory" or "very satisfactory" within the standards that made any mention or were related to interdisciplinary practice: team meeting, integrated agenda, actions agreed on previously, flexibility with demands, and a joint development of continuing education activities. These activities primarily reflect the matrix support defined as a working methodology that aims to provide to the basic teams of specialized backup and pedagogical technical support ${ }^{13}$, when realized, to involve the discussion of cases, joint care, home visits, joint development of a singular therapeutic project, and intersectoral actions. However, it is clear that this activity is restricted to some cases of a few FHS teams, mostly in mental health or regarding the use and abuse of alcohol and other drugs.

Interdisciplinarity is recognized as a strength of the research subjects much because of their work together during the initial training period that lasted about a year, plus the strong influence of professionals linked to the mental health field who led the selection process and initial organization of the NASF in the capital city studied, as can be seen in the words of one of the participants: they say that the NASF staff who are not psychologists talk as if they were. [...] it is a sign that we are getting there... (P 5). The group considers that our organization meets the objective of the sub-dimension proposed. It considers that this was reached because of the group's initial training period (G 2 ). It can be noticed that there is a perception in the group as to the need for expanding the interdisciplinary practice beyond mental health cases.

The group identified the change in work schedules (from full-time to part-time with meeting the hour quota on Saturdays) as a problem in the interdisciplinary work process: [...] with the change of work schedules, the time that was once dedicated to continuing education, exchange of experiences/discussion of cases has been insufficient (G 2). The reduction in the time available for team meetings is viewed as one of the major barriers to interdisciplinary practice. It is only through debate and discussions that it is possible to share knowledge. Some other improvement needs are also pointed out in the skills and attitudes for advancement to be made in the practice of teamwork and consequently in interdisciplinary practice such as the development of empathy, assertiveness, and personal planning. There is a need for organizational integration and personal changes among workers. ${ }^{14}$

Also regarding interdisciplinary practice, the group finds resistance from a large part of the FHS teams, many with practices rooted in the outpatient and fragmented model in response to the demands: [...] with the teams [FHS] there is still a quest for specificity [...] there is a lack of an understanding by the teams in relation to this shared action. Their actions continue to be fragmented. Professionals who came from other services such as an outpatient clinic, come to the strategy and continue reproducing the logic of the clinic (G 3).

Working in the health care industry, especially in the primary care model with a focus on networking, requires from the worker skills concerning the autonomy and communication in relation to other 
workers. ${ }^{12,15}$ Communication is the major difference between the multidisciplinary teams in which there is fragmentation in the actions and the interdisciplinary teams in which the exchange of knowledge generates a therapeutic project shared among the various team members. ${ }^{12,15}$

The results found in this study reinforce the importance of developing skills related to communication and sharing in the work process, ${ }^{11-16}$ considering that the aspects pointed out by NASF teams as necessary for interdisciplinary work are related to the possibilities and opportunities for exchanging knowledge, joint discussions, and preparing care plans in common agreement among the professionals.

The expanded clinic, defined as "the adjustment of the theoretical cutouts of each profession to the needs of the users", ${ }^{\prime \prime 25}$ was appointed out as an additional tool with the possibility of expanding the scope of actions of the NASF professionals in order to contribute to interdisciplinarity and at the same time enhance the specificity of each one, as illustrated by the words of a participant: we have not seen the expanded clinic. For me, this is lacking. (P 5).

The inclusion of interdisciplinary training since the beginning of the college course has been identified as a strategy to minimize these difficulties encountered in the professional practice in integrated health systems. ${ }^{14,16}$ The tools of expanded clinic and matrix support are considered to be fundamental and strategic for the care network with intersectoral actions shared in the territory; however, this same author points out that one of the biggest complicating factors of the process is the insufficient training of the health professionals in dealing with the practice of co-management of the work, which includes dealing with the historical conflicts and power struggles inherent to the field of health. ${ }^{17}$

\section{Lack of knowledge of the territory}

The most prominent topic in the discussions within each NASF team during the self-evaluation process (answering the instrument AMAQ NASF SC) and in the focus group was the lack of territorial and social-epidemiological diagnosis of the population enrolled, despite the teams having knowledge of the social equipment available in the region and having also developed some intersectoral actions such as, for example, with the Child Protective Services.

The deficit in the diagnosis was pointed out as one of the crucial factors for the development of all other actions recommended in the Ministry of Health Guidelines for NASF since without information there is neither planning nor proposals. The speech transcribed below reflects this reality: it can be noticed that many specific actions related to promotion/surveillance, etc. provided in public policies and in the NASF guidelines are not considered in our planning [...] (G 4).

The NASF professionals attribute this deficient knowledge of the territory to the lack of training in tools that facilitate the search and consolidation of the territory's data, but they realize that the diagnosis is also neglected by the FHS teams: the group concludes that it needs to deepen the diagnosis of the units and territory and still get closer to the community (G1); [...] they [family health teams ] are going to put up some obstacles [to carrying a local diagnosis] and sometimes they say they have no time [...] (P 8).

The group recognizes that there is a need for training in concepts and approaches of epidemiology, administration (planning), as well as in the approach with the teams: there is still a need for greater proactivity from NASF towards being more purposeful in actions of diagnosis, health surveillance, continuing education, health promotion [...] based on the reality and needs of their territory [...] (G 4). Furthermore, the profile of some management instances and information systems provided by the Municipal Health Department of the capital city studied contribute to the lack of diagnosis of the territory and consequent reduction of the proposals geared to the community needs based on the local reality: the system is very flawed, [...] the data that is put there does not include the ones we most need in fact, even to run a population diagnosis [...] it is a system that does not talk to who is at the end [...] I think they [the management] have to talk more with us to know what we need in order to work and even to plan and envision future actions. [...] it is all top down (P 10).

The territorialization or focus on community work is often neglected by family health teams, ${ }^{18}$ whether due to work overload, lack of training for the diagnosis and planning, or whether due to the manager lacking understanding about the work process within the FHS context, requiring professionals to comply with outpatient care schedules.

This lack of knowledge of the territory hinders interdisciplinary work. There is a need for training professionals for interdisciplinary work in various aspects, ${ }^{12-19}$ among them are "skills to evaluate the product of their work and take steps to improve its quality along with a solid understanding of planning techniques domain and work organization". 20:78 
The complex network that makes up the various primary health care actors requires that there be a collective creation of work projects to give support to interdisciplinary practices. Thus, the cooperative participation of the management is essential at all levels of the health system, promoting continuing education geared to the needs of workers and the service. ${ }^{5,19}$

The territory is the main characteristic of the action of the FHS teams since it delimits the area covered, directs the actions in accordance with local demands, enables a continuous evaluation of the results, and allows the appropriate link to the actions aimed at comprehensiveness. ${ }^{1}$ The Ministry of Health incorporates the understanding that the territory is dynamic and has different dimensions: demographic, epidemiological, administrative, political, technological, social, and cultural. ${ }^{1,21}$ The view about the territory, in the context of health promotion, goes beyond the epidemiological approach, which is the mapping of endemic areas and risk related to various diseases. It considers that the territory is formed through social interactions, policies, power relations, and economic interests, and therefore is in a process of constant construction. ${ }^{19,22-23}$

In this sense, it is expected that family health teams carry out the territorialization of their areas of coverage considering environment, space, and social dynamics through dialogues established with all sectors involved in the territory as well as the specific equipment from the health area in order to get to know the social conditions and determinants of health along with the local epidemiological data. ${ }^{23-24}$

The results indicated here highlight the historic nature of the challenges faced by the health systems for the transformation of health practices toward being holistic. One of the main challenges are the issues of training the health professionals and managers, institutional organization of public policies, and social mobilization to guarantee the rights reached constitutionally. ${ }^{19,25}$ A need has also been noticed to get closer to the community's socio-cultural context, which is a prerequisite for understanding the phenomena that involve the health-disease process. ${ }^{14,16-27}$

\section{The isolation of the NASF}

The NASF teams in the capital city of this study were initially allocated to a residence rented by the Municipal Health Department, specifically to receive these professionals. The location of the house where the NASF was set up was in a district different than the location of the local management of the health district where the manager, the coordinator and the supporters and technicians who cover the region work. This physical distance from the other professionals in the health care network made it possible for the professionals from the NASF teams to get closer, who shared not only work issues, but also various informal times together such as breakfast, lunch, and leisure hours between shifts, promoting great interaction and an extremely friendly atmosphere. But what brought the professionals from the NASF teams together also brought about a physical distance from the other health units.

This physical distance caused a sense of isolation by the NASF professionals. The distant management and the lack of sharing of difficulties and joint solutions between the central coordination, the NASF teams, and the FHS teams was noticed as an important reinforcement to maintain the more reactive and less proactive behavior by the NASF: [...] the distant management [...] result in a management isolated from what should be a joint action. One issue is political in detriment to the technical relationship. Managers, for example, come to do politics and not to think strategy [FHS] within a shared logic (G 3).

The management positions of the health units, which are linked to the family health teams, are filled in a commissioned way without requiring training or experience in the healthcare area. The NASF professionals realize that this affects directly the work process of the FHS teams, reinforcing the maintenance of the outpatient logic in detriment to the actions for promoting health and developing the community: [...] the manager, because he holds a contract and a position of trust, for him not to have any problems with the ombudsman, for him not to be called, for him to not have complaints from the population, he pretty much forces the professionals to provide what could be considered almost as outpatient care (P 8).

The interaction between the teams promotes mutual understanding not only of its professionals and their practices, but also of their way of being and interacting with the "other" or "others". Only from this interaction is it possible to design an interdisciplinary practice, since this presupposes opening resistant borders historically built between the various actors in the health institutions. ${ }^{14,27-28}$

Some experiences reported in the literature from setting up the NASF teams confirm the relevance of understanding the management over the multidisciplinary team's working process, however, this has been a negative impact factor on the results 
expected. ${ }^{29,31}$ The lack of support and institutional recognition by the management can become a demotivating factor for the team. ${ }^{14,32}$

However, while it is not included as a category of analysis, it was possible to notice that NASF's selfevaluation process brought immense contributions to the reflection of the professionals about their work process, as can be seen in the following statement: [...] this instrument already helps [...] I think it made it clear that we need to review our ongoing educations, exchange experience, how we are organized, and is more purposeful for the NASF team [...] there are things that are different and we have to also value the differences [...] advance the issue of units [UABSF], think about them [...] (P 14).

Using the AMAQ-NASF SC instrument ${ }^{8}$ promoted the diversification of the discussion of the multiple interfaces of the work, making it a catalyst instrument of the debate, the diagnosis, and of the proposition of actions for improvement. This instrument, together with the focus group strategy, enabled the deepening necessary into the issues that most influence the work currently carried out by the NASF team as well as expanding the perspective of the professionals about the context in which they are inserted.

\section{CONCLUSIONS}

The process of answering the AMAQ-NASF SC instrument was permeated by intense debates and discussions among the NASF professionals and the fact that there was a single coordinator for the self-evaluation meetings was considered as a facilitator because of the need for standardizing the concepts and interpretations of the standards contained in the sub-dimensions evaluated. Thus, the self-evaluation process carried out by the instrument coupled with the focus group provided a reflection and analysis on the daily work of the teams, generating alternative proposals in order to ensure actions consistent with the guidelines for NASF. Throughout this movement we observe that our guiding question was answered and that the objective proposed was achieved, giving support for the discussion about aspects of interdisciplinarity and responsiveness in primary care.

Through this research it is also possible to see that interdisciplinarity has been sought after by the professionals working in the NASF. However, this better performance does not include the family health teams linked to this, except in some specific situations of mental health when matrix support is used for discussing and guiding the cases presented by the FHS teams.

The territory, even representing a key concept for primary care, has not been worked as such. As a result of this, there is a priority on spontaneous demands, and the care becomes restricted to isolated cases and the community is not involved very much in actions that work with the social determinants of health.

The management model adopted in the capital city studied allows for different types of employment relationships between the various professionals of the team and of the health care network, including with managers coming into the system through temporary contracts in commissioned positions. This hinders the commitment of management to the change in the care model and outpatient care logic, both individualized and medical-centered. In this context, NASF workers view themselves as isolated from the other actors belonging to the health system and resent the lack of support from higher authorities.

Therefore, this study indicates that there are challenges to be overcome so that the professionals from multidisciplinary team are not swallowed up by the prevailing logic in outpatient health practices: shared management, but with accountability of decision makers; continuing improvement and education by the multidisciplinary team in diagnostic and planning tools; and development of skills and abilities to communicate and work with the various groups with which they relate to within primary care (family health strategy teams, workers of the other levels of the health care network, community, institutions, and social equipment). In addition, it is necessary to meet the urgent and growing need to invest in training of all involved in the work process in primary care, including management. Also important is the awareness of the family health teams with the support model in the logic of greater responsiveness in the health unit itself and the discussion and appropriation by the health workers of the concepts of interdisciplinarity and transdisciplinarity.

\section{REFERENCES}

1. Ministério da Saúde (BR), Secretaria de Atenção à Saúde, Departamento de Atenção Básica. Política Nacional de Atenção Básica. Brasília (DF): MS; 2012.

2. Brasil. Portaria n. 154/GM de 24 de janeiro de 2008: cria os Núcleos de Apoio à Saúde da Família - NASF. Diário Oficial da República Federativa do Brasil, n. 18, 26 jun 2001, Seção 1. 
3. Ministério da Saúde (BR), Secretaria de Atenção à Saúde, Departamento de Atenção Básica, Departamento de Ações Programáticas Estratégicas. Diretrizes do NASF: Núcleo de Apoio a Saúde da Família. Série A. Normas e manuais técnicos. Cadernos de Atenção Básica, n. 27. Brasília (DF): MS; 2009.

4. Ministério da Saúde (BR), Secretaria de Atenção à Saúde, Departamento de Atenção Básica. Autoavaliação para a melhoria do acesso e da qualidade da Atenção Básica: AMAQ. Brasília (DF): MS; 2012.

5. Cameron A, Lart R, Bostock L, Coomber C. Factors that promote and hinder joint and integrated working between health and social care services: a review of research literature. Health Soc Care Community. 2014 May; 22(3):225-33.

6. Contandriopoulos AP, Champagne F, Denis JL, Pineault R. A avaliação na área da saúde: conceitos e métodos. In: Hartz ZMA, organizador. Avaliação em Saúde: dos modelos conceituais à prática na análise da implantação de programas. Rio de Janeiro: Editora Fiocruz; 1997. p. 29-47.

7. Felisberto E. Da teoria à formulação de uma Política Nacional de Avaliação em Saúde: reabrindo o debate. Ciênc Saúde Coletiva. 2006; 11(3):553-63.

8. Núcleo Telessaúde da Secretaria de Saúde do Estado de Santa Catarina. Autoavaliação para melhoria do acesso e da qualidade da Atenção Básica/ NASF SC: AMAQ-NASF SC. Florianópolis (SC): Universidade Federal de Santa Catarina; 2012.

9. Minayo MCS, editor. Pesquisa social: teoria, método e criatividade. 31 ${ }^{\mathrm{a}}$ ed. Petrópolis (RJ): Vozes; 2012.

10. Bardin L. Análise de conteúdo. $3^{\mathrm{a}}$ ed Lisboa (PT): 70; 2004.

11. Scherer MDA, Pires DEP, Rémy J. A construção da interdisciplinaridade no trabalho da Equipe de Saúde da Família. Ciênc Saúde Coletiva. 2013; 18(11):3203-12.

12. Schultz CR, Walker R, Bessarab D, McMillan F, Macleod J, Marriott R. Interdisciplinary care to enhance mental health and social and emotional wellbeing. In: Dudgeon P, Milroy H, Walker R, organizadores. Working together: aboriginal and torres strait islander mental health and wellbeing principles and practice. barton. Camberra (AU): Australian Government Department of the Prime Minister and Cabinet; 2014.

13. Campos GWS, Domitti AC. Apoio matricial e equipe de referência: uma metodologia para gestão do trabalho interdisciplinar em saúde. Cad Saúde Pública. 2007; 23(2):399-407.

14. Iliadi P. Accountability and Collaborative Care: How interprofessional education promotes them. Health Science J. 2010; 4(3):129-35.

15. Peduzzi M. Multiprofessional healthcare team: concept and typology. Rev Saúde Pública. 2001; 35(1):103-9.
16. Barwell J, Arnold F, Berry H. How interprofessional learning improves care. Nurs Times. 2013; 109(21):14-6.

17. Campos GWS. Apoio matricial e práticas ampliadas e compartilhadas em redes de atenção. Psicol Rev. 2012; 18(1):148-68.

18. Sala A, Luppi CG, Simões O, Marsiglia RG. Integralidade e Atenção Primária à Saúde: avaliação na perspectiva dos usuários de unidades de saúde do município de São Paulo. Saúde Soc. 2011; 20(4):948-60.

19. Thomas K, Krevers B, Bendtsen P. Implementing healthy lifestyle promotion in primary care: a quasiexperimental cross-sectional study evaluating a team initiative. BMC Health Serv Res. 2015; 15(31): 1-10.

20. Peduzzi M. Mudanças tecnológicas e seu impacto no processo de trabalho em saúde. Trab Educ Saúde. 2003; 1(1):75-91.

21. Ministério da Saúde (BR), Secretaria de Vigilância em Saúde. Série B. Textos Básicos de Saúde. Política nacional de promoção da saúde. Brasília (DF): MS; 2006.

22. Perekehouskei NA, Benaduce GMC. Geografia da saúde e as concepções sobre o território. Gestão \& Regionalidade. 2007; 23 (68): 34-44.

23. Santos AL, Rigotto RM. Território e territorialização: incorporando as relações produção, trabalho, ambiente e saúde na Atenção Básica à Saúde. Trab Educ Saúde. 2010; 8(3):387-406.

24. Gondim GMM, Monken M, Iñiguez Rojas L, Barcellos C, Peiter P, Navarro MBMA et al. O território da saúde: a organização do sistema de saúde e a territorialização. In: Miranda AC, Barcellos C, Moreira JC, Monken M, organizadores. Território, ambiente e saúde. Rio de Janeiro: Editora Fiocruz; 2008. p. 237-55.

25. Göttems LBD, Pires MRGM. Para além da Atenção Básica: reorganização do SUS por meio da interseção do setor político com o econômico. Saúde Soc. 2009; 18(2):189-98.

26. Almeida NAM, Medeiros M, Souza MR. Perspectives of normal delivery pain of primigravid during the antenatal period. Texto Contexto Enferm. 2012 [acesso 2014 Nov 05]; 21(4):819-27.Disponível em: http:/ / www.scielo.br/scielo.php?pid=S010407072012000400012\&script=sci_arttext\&tlng=en

27. Petch A. Integration of health and social care. IRISS Insights. 2012; 14: 1-12.

28. Bridges DR, Davidson RA, Odegard PS, Maki IV, Tomkowiak J. Interprofessional collaboration: three best practice models of interprofessional education. Med Educ Online [online]. 2011 [acesso 2014 Nov 05]; 16: 6035-45. Dipsonível em: http://www.ncbi.nlm. nih.gov/pmc/articles/PMC3081249/

29. Martiniano CS, Sampaio J, Magalhães FC, Souza FF, Marcolino EC, Rocha AMO. Review of implementation of the teams of nuclei of support for family health. Rev Enferm UFPE Online [online]. 2013 [acesso 2014 Nov 05]; 7(1):53-61. Dipsonível em: http:/ / www.revista. 
ufpe.br/revistaenfermagem/index.php/revista/ article/view/3684/pdf_1808

30. Sampaio J, Sousa CSM, Marcolino EC, Magalhães FC, Souza FF, Rocha AMO, et al. O NASF como dispositivo da gestão: limites e possibilidades. Rev Bras Ciênc Saúde. 2012; 16(3):317-24.
31. Santos SFS, Benedetti TRB. Cenário de implantação do Núcleo de Apoio a Saúde da Família e a inserção do profissional de Educação Física. Rev Bras Ativ Fis Saúde. 2012; 17(3):188-94.

32. Matos E, Pires DEP, Ramos FRS. Expressões da subjetividade no trabalho de equipes interdisciplinares de saúde. REME Rev Min Enferm. 2010; 14(1):56-97. 